\title{
The impact of endocrine disruptor chemicals on oocyte/embryo and clinical outcomes in IVF
}

\author{
Rosalie Cabry' ${ }^{1}$, Philippe Merviel ${ }^{2}$, Aicha Madkour $\mathbb{D}^{3}$, Elodie Lefranc ${ }^{1}$, Florence Scheffler ${ }^{1}$, Rachel Desailloud ${ }^{1}$, \\ Véronique Bach ${ }^{1}$ and Moncef Benkhalifa ${ }^{1}$
}

${ }^{1}$ Amiens University, Amiens, Haut-de-France, France

${ }^{2}$ Brest University, Brest, Bretagne, France

${ }^{3}$ Mohammed V University of Rabat, Reproductive Medicine, Rabat, Morocco

Correspondence should be addressed to M Benkhalifa: benkhalifamoncef78@gmail.com

\begin{abstract}
The negative impact of endocrine-disrupting pesticides on human fertility is now a key issue in reproductive health. There are much fewer literature data about the impact of pesticide exposure on women than on men and very few studies of women participating in an in vitro fertilization (IVF) programme. In the present review, we found that (1) various pesticides with an endocrine-disrupting action are associated with poor oocyte maturation and competency, embryonic defects and poor IVF outcomes, and (2) some pesticide compounds are linked to specific causes of female infertility, such as premature ovarian insufficiency, polycystic ovarian syndrome, and endometriosis. IVF participants living in agricultural regions should be informed about the fertility decline, low ongoing pregnancy rates, and elevated risk of miscarriage associated with exposure to high doses of pesticides.
\end{abstract}

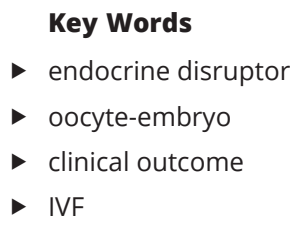

Endocrine Connections (2020) 9, R134-R142

\section{Introduction}

Infertility is defined as failure to obtain a clinical pregnancy after 12 months of regular, unprotected sexual intercourse. On average, it affects $8-12 \%$ of couples of child-bearing age (1). A decline in human fertility has prompted an increasing proportion of couples to enrol in in vitro fertilization (IVF) programmes. Over the last 50 years, the sperm count has fallen by $32-50 \%$ in Europe and United States $(2,3)$; this fall is too rapid to be due to a genetic factor but might be related to one or more environmental factors, such as exposure to pesticides.

Pesticide are substances or combinations of substances used in many areas of agriculture and industry. They include (1) phytosanitary products (also referred to as phytopharmaceuticals) used in agricultural or nonagricultural plant sectors to control insects (insecticides), weeds (herbicides), fungi and moulds (fungicides), or pests (rodenticides); (2) biocides used in industry (treatment of wood and textiles), hospital environments (hydroalcoholic gels), and domestic settings (disinfection); and (3) antiparasitics used in human and veterinary medicine (treatment of lice, scabies, mites, fleas, ticks, etc.) $(4,5)$.

The main families of pesticides by chemical composition are as follows:

- Organophosphorus (OP) compounds, such as chlorpyrifos, cypermethrin, malathion, and parathion

- Organochlorine (OC) compounds, such as methoxychlor (MXC), 2,3,7,8-tetrachlorodibenzopdioxin (TCDD), dichlorodiphenyldichloroethane (DDD), dichlorodiphenyldichloroethylene (DDE), dichlorodiphenyltrichloroethane (DDT), polychlorinated biphenyls (PCBs), dieldrin, endosulfan, hexachlorobenzene (HCB), hexachlorocyclohexane $(\mathrm{HCH})$, and lindane

- Carbamates, such as carbofuran, benomyl, and mancozeb

- Pyrethroids, such as permethrin

- Triazines, such as atrazine
This work is licensed under a Creative Commons Attribution-NonCommercial 4.0 International License. ded from Bioscientifica.com at 04/26/2023 10:54:52AM 
Many pesticides are known to be endocrine-disrupting chemicals (EDCs), defined as 'exogenous agents, that are potentially capable of synthesis, secretion, transport, binding, action, or elimination of the natural hormones responsible for the maintenance of homeostasis, reproduction, and developmental processes in the body' (5). Even though the involvement of EDCs in certain reproductive diseases is well documented, only few studies have examined the direct impact of pesticides on fertility (and especially in female infertility) in IVF programmes. Hence, the objective of the present review was to assess the impact of the most frequently used pesticides on female fertility, oocyte-embryo quality, and clinical outcomes in IVF programmes.

\section{Pesticides as EDCs}

A large body of evidence from animal studies and epidemiological surveys shows that pesticides like bisphenol A (BPA) and phthalates have an endocrine-disrupting action and a reprotoxic impact $(5,6,7,8,9,10,11)$. Furthermore, Manikkam (12) highlighted the existence of a transgenerational risk in the rat: in utero exposure of pups to a mixture of pesticides (administered by gavaging the pregnant dams) was associated with changes in puberty onset, spermatogenesis, and the development of ovarian follicles up to the F3 generation.

The direct, toxic endocrine-disrupting effect (i.e. a dose-response relationship) has rarely been characterized for a single target compound. In general, the major toxic exposure is associated with a large number of lowdose compounds and the interactions between these compounds. This 'cocktail effect' is why the presence of even very small amounts of some specific pesticides can perturb an organism's hormonal balance $(13,14)$. Indeed, some pesticides bind as agonists to hormone receptors, which results in direct cell damage and/or the dysregulation of one or more biochemical or genetic pathways. In turn, this dysregulation produces toxic metabolites and increases the level of oxidative stress (14), which affects both male and female fertility. There are more research data on the influence of various pesticides on male fertility than on female fertility. However, even the data on male fertility (with putative links between exposure and a range of disorders), especially those correlated with poor sperm quality and low testicular weight $(15,16,17)$, make it hard to affirm the presence of a direct, causal effect in humans.
Compounds such as lindane, PCB, atrazine, and mancozeb might dysregulate hormonal status in women by decreasing LH concentrations and thus promoting oligo-ovulation/anovulation and follicle destruction $(13,14)$.

\section{Pesticide exposure and female fertility}

In 1994, De Cock et al. (18) investigated the impact of pesticide exposure in market gardeners in the Netherlands and found that the fecundability ratio fell as the intensity of pesticide exposure increased. In this study, $28 \%$ of couples in the 'high exposure' group and $8 \%$ of the couples in 'low exposure' group requested assisted reproductive technology (ART) support. Other studies have emphasized this effect of pesticide exposure in women, with lengthening of the time required to conceive $(19,20,21,22)$. A risk of spontaneous miscarriage has also been observed, particularly in Bretveld et al.'s (23) study of female farmers (odds ratio $(95 \% \mathrm{CI})=4.0(1.14-14.01)$.

Data from the Agricultural Health Study cohort showed that menstrual cycles of women exposed to pesticides increased in length, although no distinction was made between occupational exposure and domestic exposure (24).

These results clearly converge on an impact of pesticide use (especially in an occupational setting) on female reproductive capacity and certain female infertility diseases, such as premature ovarian failure (POF), polycystic ovarian syndrome (PCOS), and endometriosis. Furthermore, pesticide exposure might have direct or indirect effects on oocyte/embryo quality and the clinical outcomes of IVF.

\section{The association between pesticide exposure and certain female infertility diseases}

The negative impact of pesticides has been investigated in animal experiments. Many deficiencies have been described, such as low ovarian weight $(25,26)$, impaired folliculogenesis (27), a high aneuploidy rate, and the acceleration of follicular atresia $(25,26,27)$.

Indeed, women exposed to some endocrine-disrupting pesticides (such as atrazine, lindane, and maneb) have an elevated risk of long menstrual cycles or anovulation (13). Conversely, high blood levels of DDE (28) and DDT (29) are associated with luteal phase deficiency and short menstrual cycles. The most serious consequence is POF (Premature Ovarian failure), defined as the cessation

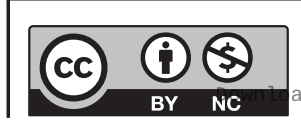

This work is licensed under a Creative Commons Attribution-NonCommercial 4.0 International License. ded from Bioscientifica.com at 04/26/2023 10:54:52AM 
of menstrual cycles before the age of 40 years and characterized by very low blood levels of anti-Müllerian hormone (AMH). The prevalence of POF is around $1 \%$, as a result of genetic or autoimmune/metabolic factors or cancer therapy (1). Nonetheless, POF might sometimes be caused by environmental factors, including pesticide exposure. Indeed, a few studies have linked exposure to $\mathrm{HCH}$, mirex (30), pyrethroids (31), and their metabolites (especially 3-phenoxybenzoic acid (32)), PCB, and DDT (33) to ovarian ageing and menopause at an earlier average age. Interestingly, low AMH levels were associated with the presence of DDT in the serum (detected in more than $40 \%$ of samples from patients with POF (33)) and with high concentrations of pyrethroids and their metabolites with $25-26 \%$ reduction $(31,32)$.

The presence of DDE, MXC, or simazine (a triazine herbicide) was associated with follicular atresia (34). Given that MXC, simazine, and other pesticides (as atrazine, endosulfan, and chlordecone) are oestrogen receptor agonists (in contrast to DDE, DDT, and vinclozolin), they may have oestrogenic and/or antiandrogenic effects $(5,10,35,36)$. This implicitly explains why some specific pesticides could be responsible for various female reproductive diseases to differing extents and why the effects of some pesticide compounds (such as DDE, PCB, and MXC) depend on the patient's genetic predisposition. Indeed, these pesticides were associated with abnormally high AMH levels and a high number of small antral follicles - reflecting the presence of PCOS (37, $38,39)$. Polycystic ovarian syndrome is a heterogeneous condition that affects $5-10 \%$ of women. According to the Rotterdam diagnostic criteria for PCOS, two of the following three criteria must be met: infrequent or absent ovulation (oligospaniomenorrhea), an abnormal ovarian morphology on ultrasound, and hyperandrogenism (1).

Moreover, some pesticides (such as TCDD (40, 41, 42), PCB (43), and permethrin (44)) have a documented impact on the endometrium by increasing vascularization, cell proliferation, VEGF levels, and thus endometriosis (with prevalence of 0.8-6\%) (1). However, other pesticides (cypermethrin (45), chlorpyrifos, malathion, diazinon, lindane, DDT, and pyrethroids (46)) have the opposite effect by indirectly inhibiting endometrial proliferation or causing oxidative damage to the uterus.

Many studies have found an association between pesticide concentrations in the follicular fluid on one hand and the number and quality of oocytes collected for IVF $(47,48)$, endometrial thickness, and embryo implantation rates (46) on the other. Studies of animal models have shown that pesticide exposure is associated with elevated oxidative stress, which may be responsible for the observed alterations (49).

\section{Impact on oocyte quality}

Exposure to pesticides might cause generalized oxidative stress (49), with the elevated production of free radicals and impacts on superoxide dismutase, catalase, glutathione peroxidase, glutathione reductase, and glutathione transferase. This might explain why oocyte quality is impacted; oocyte dysmorphisms may reflect poor competence for development into a good embryo for implantation.

Indeed, we have highlighted (50) a conclusive link between a high prevalence (>75\%) of oocytes with centrally located cytoplasm granulation (CLCG) and the patients' exposure to pesticides in the highly agricultural Picardy area of northern France (annual pesticide consumption: $~ 3900$ tons). As a result, ongoing pregnancy and live birth rates were lower in couples with a high prevalence of oocytes with CLCG than in couples with low (<25\%) prevalence (14\% vs $32 \%$ for the ongoing pregnancy rate and $13 \%$ vs $30 \%$ for the live birth rate, respectively). Conversely, the early miscarriage rate was higher (47\%) in the high-prevalence group than in the low-prevalence group (11\%; odds ratio: 3.1$)$. This poor IVF outcome might be indirectly due to high levels of pesticide exposure (over $3000 \mathrm{~g} / \mathrm{ha}$ ), which engenders a higher risk of oocytes with CLCG.

In line with these results, some pesticides (e.g. atrazine, cypermethrine, DDT, dieldrine, MCX, and vinclozoline) affect folliculogenesis (via the granulosa and theca cells) and thus induce meiotic aberrations (aneuploidy) and follicular atresia (51). For example, DDT stimulates aromatase and acts in synergy with FSH to induce a premature rise in oestradiol levels, affecting oocyte maturation (51). Furthermore, PCB might damage the ovarian reserve, the follicular response to administered gonadotropins, and oocyte maturation (51). Indeed, exposure of immature porcine cumulus-oocyte complexes to an organochlorine mixture (48) or atrazine (52) during in vitro maturation was associated with an elevated incidence of incompletely matured oocytes. The researchers mentioned the following pathophysiological mechanisms: abnormal cellular shape (disrupted spindle morphology), abnormal mitochondrial activity, and alterations in oocyte DNA $(48,51,52)$.

The pesticides most frequently linked to defective oocyte maturation and oocyte competence are malathion (53), parathion (54), MXC (55), DDD/DDE/DDT/PCB 
؛ํ.

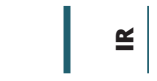

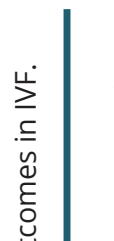
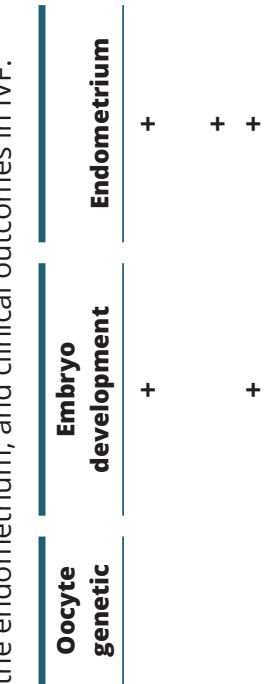

究|

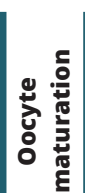

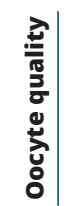

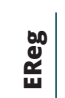

ֻே.
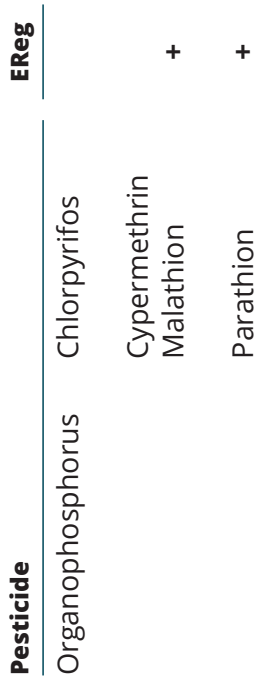

气

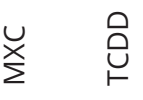

음ㄴㅁㅁ

$\ddagger \ddagger$

$\ddagger$

号

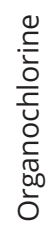

$\ddagger$

$\stackrel{+}{\ddagger}$

$\ddagger$

$\ddagger$

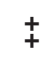

$\ddagger$

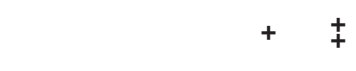

$\ddagger \quad+\quad+\quad+$

$\stackrel{\dddot{Q}}{\Omega}$

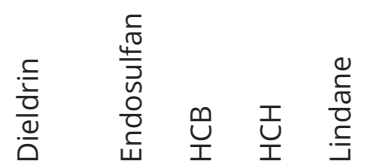




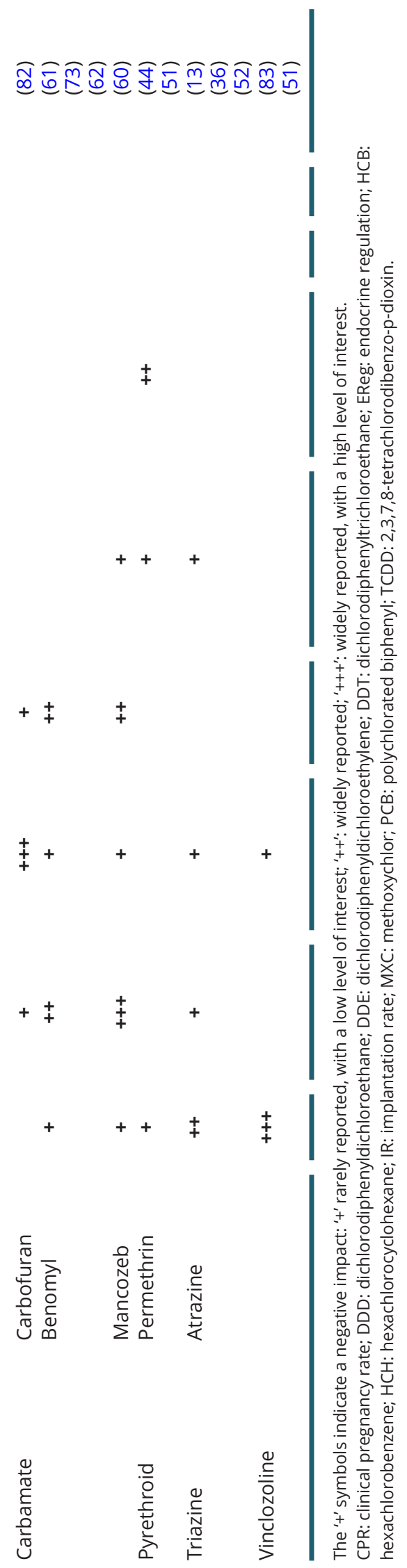

https://ec.bioscientifica.com https://doi.org/10.1530/EC-20-0135
(56, 57), dieldrin (58), $\mathrm{HCB} / \mathrm{HCH}$ (47), lindane (59), benomyl (60), and mancozeb $(61,62)$ (Table 1$)$.

Interestingly, DDT was associated with a low proportion of diploid oocytes (56), while benomyl interfered with microtubules (60) and lindane was associated with cell damage (especially vacuolation and cytoplasmic fragmentation) (59). It was reported that mancozeb can strongly affect the meiotic spindle organization of oocytes (61), but the degree of damage could be decreased by treatment with resveratrol (62).

Moreover, exposure to deltamethrin (another common insecticide) in a mouse model was linked to cellular oxidative stress and meiotic abnormalities via DNA damage (63). Liu et al. (49) suggested that MXC exposure induces oxidative stress and affects mouse oocyte meiotic maturation via the accumulation of superoxide radicals and other reactive oxygen species (ROS), aberrant mitochondrial distribution, a low mitochondrial membrane potential, and elevated lipid peroxidation. Thus, exposure to MXC can negatively affect oocyte meiotic maturation - primarily through impairments in cellular metabolism. In general, all these pesticide-linked defects in oocyte quality are likely to degrade competence for the development of a genetically undamaged embryo.

\section{Impact on embryo development}

Pesticides can affect indirectly the embryo by dysregulating embryonic genome activation and embryonic metabolism, which is dependent on oxygen uptake. This latter is low at the 8 -cell stage $(64,65,66)$ and tends to increase after the morula stage required for blastocyst expansion (67). Blastocyst formation and the number of cells per blastocyst declined with the concentration of organochlorines (48) and atrazine (52). Furthermore, the association of pesticides like deltamethrin (63) and MXC (49) with poor metabolic and genetic status during embryo development might be due to the impairment of various biochemical pathways (13) and high ROS production. Moreover, high ROS concentrations and generalized oxidative stress are likely to affect the integrity of cellular constituents, such as DNA and proteins $(68,69,70)$.

Various pesticides (especially chlorpyrifos with endosulfan (71), malathion (53), DDE/DDT/PCB $(56,47)$, dieldrin (72), mancozeb (73) (Table 1), and pretilachlor/ diazinon (46)) may impact negatively embryonic development. Consequently, the use of low-quality embryos associated with pesticide exposure would give poor clinical outcomes (e.g. an elevated risk of miscarriage) in IVF programmes. (c) 2020 The authors Published by Bioscientifica Ltd 


\section{Impact on clinical outcomes in IVF programmes}

Women who consume high levels of pesticide residues in fruits and vegetables (74) or who live in an area with high pesticide exposure $(50,75)$ have an above-average risk of miscarriage. In one study, the probability of clinical pregnancy was $18 \%$ below average and the live birth rate was $26 \%$ below average in the women most exposed to pesticides (74). However, in a study in California, there were no differences in terms of spontaneous miscarriage, preeclampsia, and preterm birth rates between women exposed to pesticides (occupationally or through residence in an agricultural area) and unexposed women (76). Pesticides associated with poor clinical outcomes in IVF are chlorpyrifos (46), TCDD (42), DDT/PCB (46, $56,77,78), \mathrm{HCB} / \mathrm{HCH}(47,56,57)$, and endosulfan (79) (Table 1). Lindane, DDT, diazinon, and chlorpyrifos were associated with a low implantation rate but did not have a clear impact on the clinical pregnancy and live birth rates (46). Nevertheless, PCB and endosulfan have been linked to repeated implantation failures $(77,79)$.

\section{Conclusion}

A growing number of studies have assessed the putative causal link between exposure to pesticides and female fertility disorders. Although awareness of these issues has increased, the literature data are too scarce for conclusive, decisive recommendations. The impact of exposure to various endocrine-disrupting pesticides on fertility is now a public health issue that urgently requires the performance of more epidemiological studies - especially those focused on female fertility and women in IVF programmes. Furthermore, it is important to design studies that assess the severity of exposure and the nature of pesticides. There is also a need to develop more specific, rapid diagnosis techniques and treatments that might decrease pesticideinduced damage. Indeed, IVF participants living in agricultural regions should be informed about the fertility decline, low ongoing pregnancy rates, and elevated risk of miscarriage associated with exposure to high doses of pesticides.

\section{Declaration of interest}

The authors declare that there is no conflict of interest that could be perceived as prejudicing the impartiality of this review.

\section{Funding}

This work was funded by Amiens-Picardie University Hospital (Amiens, France) and Jules Verne University of Picardie (Peritox Laboratory, Amiens, France).

\section{Acknowledgements}

The authors thank the staff at Amiens-Picardie University Hospital's ART unit and the staff at the Peritox Laboratory for their support.

\section{References}

1 Vander Borght $\mathrm{M} \&$ Wyns C. Fertility and infertility: definition and epidemiology. Clinical Biochemistry 201862 2-10. (https://doi. org/10.1016/j.clinbiochem.2018.03.012)

2 Manikkam M, Tracey R, Guerrero-Bosagna C \& Skinner MK. Pesticide and insect repellent mixture (permethrin and DEET) induces epigenetic transgenerational inhtitance of disease and sperm epimutations. Reproductive Toxicology 201234 708-719. (https://doi. $\operatorname{org} / 10.1016 /$ j.reprotox.2012.08.010)

3 Levine H, Jørgensen N, Martino-Andrade A, Mendiola J, WekslerDerri D, Mindlis I, Pinotti R \& Swan SH. Temporal trends in sperm count: a systematic review and meta-regression analysis. Human Reproduction Update 201723 646-659. (https://doi.org/10.1093/ humupd/dmx022)

4 Sengupta P, Borges E, Dutta S \& Krajewska-Kulak E. Decline in sperm count in European men during the past 50 years. Human and Experimental Toxicology 201837 247-255. (https://doi. org/10.1177/0960327117703690)

5 Alavanja MC. Introduction: pesticides use and exposure, extensive worldwide. Reviews on Environmental Health 200924 303-309. (https://doi.org/10.1515/reveh.2009.24.4.303)

6 Sifakis S, Mparmpas M, Soldin OP \& Tsatsakis A. Pesticide exposure and health related issues in male and female reproductive system. In Pesticides-Formulations, Effects, Fate. London, UK: Intech Open, 2011. (https://doi.org/10.5772/15845)

7 Rocheleau CM, Romitti PA \& Dennis LK. Pesticides and hypospadias: a meta-analysis. Journal of Pediatric Urology 20095 17-24. (https://doi. org/10.1016/j.jpurol.2008.08.006)

8 Carmichael SL, Yang W, Roberts EM, Kegley SE, Wolff C, Guo L, Lammer EJ, English P \& Shaw GM. Hypospadias and residential proximity to pesticide applications. Pediatrics 2013132 e1216-e1226. (https://doi.org/10.1542/peds.2013-1429)

9 Haraux E, Tourneux P, Kouakam C, Stephan-Blanchard E, Boudailliez B, Leke A, Klein C \& Chardon K. Isolated hypospadias: the impact of prenatal exposure to pesticides, as determined by meconium analysis. Environment International 2018119 20-25. (https://doi.org/10.1016/j.envint.2018.06.002)

10 Mnif W, Pillon A, Balaguer P \& Bartegi A. Endocrine xenoestrogenics disrupters, molecular mechanisms and detection methods. Therapie 200762 369-386. (https://doi.org/10.2515/therapie:2007062)

11 Bhardwaj JK \& Saraf P. Granulosa cell apoptosis by impairing antioxidant defense system and cellular integrity in caprine antral follicles post Malathion exposure. Environmental Toxicology 201631 1944-1954. (https://doi.org/10.1002/tox.22195)

12 Ma Y, He X, Qi K, Wang T, Qi Y, Cui L, Wang F \& Song M. Effects of environmental contaminants on fertility and reproductive health. Journal of Environmental Sciences 201977 210-217. (https://doi. org/10.1016/j.jes.2018.07.015)

13 Farr SL, Cooper GS, Cai J, Savitz DA \& Sandler DP. Pesticide use and menstrual cycle characteristics among premenopausal women in the Agricultural Health Study. American Journal of Epidemiology 2004160 1194 1204. (https://doi.org/10.1093/aje/kwi006)

14 Bretveld RW, Thomas CM, Scheepers PT, Zielhuis GA \& Roeleveld N. Pesticide exposure: the hormonal function of the female reproductive system disrupted? Reproductive Biology and Endocrinology 20064 30. (https://doi.org/10.1186/1477-7827-4-30)

15 Joshi SC, Mathur R \& Gulati N. Testicular toxicity of chlorpyrifos (an organophosphate pesticide) in albino rat. Toxicology and Industrial Health 200723 439-444. (https://doi. org/10.1177/0748233707080908) 
16 Akhtar N, Srivastava MK \& Raizada RB. Assessment of chlorpyrifos toxicity on certain organs in rat, Rattus norvegicus. Journal of Environmental Biology 200930 1047-1053.

17 Farag AT, Radwan AH, Sorour F, El Okazy A, El-Agamy el-S \& El-Sebae Ael-K. Chlorpyrifos induced reproductive toxicity in male mice. Reproductive Toxicology 201029 80-85. (https://doi. org/10.1016/j.reprotox.2009.10.003)

18 De Cock J, Westveer K, Heederik D, te Velde E \& van Kooij R. Time to pregnancy and occupational exposure to pesticides in fruit growers in the Netherlands. Occupational and Environmental Medicine 199451 693699. (https://doi.org/10.1136/oem.51.10.693)

19 Curtis KM, Savitz DA, Weinberg CR \& Arbuckle TE. The effect of pesticide exposure on time to pregnancy. Epidemiology 199910 112117. (https://doi.org/10.1097/00001648-199903000-00005)

20 Harley KG, Marks AR, Bradman A, Barr DB \& Eskenazi B. DDT exposure, work in agriculture, and time to pregnancy Among farmworkers in California. Journal of Occupational and Environmental Medicine 200850 13351342. (https://doi.org/10.1097/ JOM.0b013e31818f684d)

21 Idrovo AJ, Sanìn LH, Cole D, Chavarro J, Cáceres H, Narváez J \& Restrepo M. Time to first pregnancy among women working in agricultural production. International Archives of Occupational and Environmental Health $2005 \mathbf{7 8}$ 493500. (https://doi.org/10.1007/ s00420-005-0615-9)

22 Abell A, Juul S \& Bonde JPE. Time to pregnancy among female greenhouse workers. Scandinavian Journal of Work, Environment and Health 200026 131136. (https://doi.org/10.5271/sjweh.522)

23 Bretveld RW, Hooiveld M, Zielhuis GA, Pellegrino A, van Rooij IALM \& Roeleveld N. Reproductive disorders among male and female greenhouse workers. Reproductive Toxicology 200825 107-114. (https://doi.org/10.1016/j.reprotox.2007.08.005)

24 Alavanja MC, Sandler DP, McMaster SB, Zahm SH, McDonnell CJ, Lynch CF, Pennybacker M, Rothman N, Dosemeci M, Bond AE, et al. The agricultural health study. Environmental Health Perspectives 1996 104 362369. (https://doi.org/10.1289/ehp.96104362)

25 Park S, Kim S, Jin H, Lee K \& Bae J. Impaired development of female mouse offspring maternally exposed to simazine. Environmental Toxicology and Pharmacology 201438 845-851. (https://doi. org/10.1016/j.etap.2014.10.008)

26 El-Sharkawy EE, Kames AO, Sayed SM, Nisr NA, Wahba NM, Elsherif WM, Nafady AM, Abdel-Hafeez MM \& Aamer AA. The ameliorative effect of propolis against methoxychlor induced ovarian toxicity in rat. Experimental and Toxicologic Pathology 201466 415-421. (https://doi.org/10.1016/j.etp.2014.06.003)

27 Satar DA, Tap O \& Ay MO. Electron microscopic examination of the effects of methyl parathion exposure on the ovaries. European Review for Medical and Pharmacological Sciences 201519 2725-2731.

28 Windham GC, Lee D, Mitchell P, Anderson M, Petreas M \& Lasley B. Exposure to organochlorine compounds and effects on ovarian function. Epidemiology 200516182 190. (https://doi.org/10.1097/01. ede.0000152527.24339.17)

29 Ouyang F, Perry MJ, Venners SA, Chen C, Wang B, Yang F, Fang Z, Zang T, Wang L, Xu X, et al. Serum DDT, age at menarche, and abnormal menstrual cycle length. Occupational and Environmental Medicine 200562 878-884. (https://doi.org/10.1136/ oem.2005.020248)

30 Grindler NM, Allsworth JE, Macones GA, Kannan K, Roehl KA \& Cooper AR. Persistent organic pollutants and early menopause in U.S. Women. PLOS ONE 201510 e0116057. (https://doi.org/10.1371/ journal.pone.0116057)

31 Whitworth KW, Baird DD, Steiner AZ, Bornman RM, Travlos GS, Wilson RE \& Longnecker MP. AntiMüllerian hormone and lifestyle, reproductive, and environmental factors among women in rural South Africa. Epidemiology 201526 429-435. (https://doi. org/10.1097/EDE.0000000000000265)
32 Li C, Cao M, Ma L, Ye X, Song Y, Pan W, Xu Z, Ma X, Lan Y, Chen P, et al. Pyrethroid pesticide exposure and risk of primary ovarian insufficiency in Chinese women. Environmental Science and Technology 201852 3240-3248. (https://doi.org/10.1021/acs.est.7b06689)

33 Pan W, Ye X, Yin S, Ma X, Li C, Zhou J, Liu W \& Liu J. Selected persistent organic pollutants associated with the risk of primary ovarian insufficiency in women. Environment International 2019129 51-58. (https://doi.org/10.1016/j.envint.2019.05.023)

34 Vabre P, Gatimel N, Moreau J, Gayrard V, Picard-Hagen N, Parinaud J \& Leandri RD. Environmental pollutants, a possible etiology for premature ovarian insufficiency: a narrative review of animal and human data. Environmental Health 201716 37. (https://doi. org/10.1186/s12940-017-0242-4)

35 Kadhel P, Monnier P, Boucoiran I, Chaillet N \& Fraser WD. Organochlorine pollutants and female fertility: a systematic review focusing on in vitro fertilization studies. Reproductive Sciences 201219 1246-1259. (https://doi.org/10.1177/1933719112446077)

36 Samardzija D, Pogrmic-Majkic K, Fa S, Glisic B, Stanic B \& Andric N. Atrazine blocks ovulation via suppression of Lhr and Cyp19a1 mRNA and estradiol secretion in immature gonadotropin-treated rats. Reproductive Toxicology 201661 10-18. (https://doi.org/10.1016/j. reprotox.2016.02.009)

37 Manikkam M, Haque MM, Guerrero-Bosagna C, Nilsson EE \& Skinner MK. Pesticide methoxychlor promotes the epigenetic transgenerational inheritance of adult-onset disease through the female germline. PLOS ONE 20149 e102091. (https://doi. org/10.1371/journal.pone.0102091)

38 Zhang J, Liu XF, Liu Y, Xu LZ, Zhou LL, Tang LL, Zhuang J, Li TT, Guo WQ, Hu R, et al. Environmental risk factors for women with polycystic ovary syndrome in china: a population-based case-control study. Journal of Biological Regulators and Homeostatic Agents 201428 203-211.

39 Yang Q, Zhao Y, Qiu X, Zhang C, Li R \& Qiao J. Association of serum levels of typical organic pollutants with polycystic ovary syndrome (PCOS): a case-control study. Human Reproduction 201530 1964-1973. (https://doi.org/10.1093/humrep/dev123)

40 Bofinger DP, Feng L, Chi LH, Love J, Stephen FD, Sutter TR, Osteen KG, Costich TG, Batt RE, Koury ST, et al. Effect of TCDD exposure on CYP1A1 and CYP1B1 expression in explant cultures of human endometrium. Toxicological Sciences 200162 299-314. (https://doi.org/10.1093/toxsci/62.2.299)

41 Nayyar T, Bruner-Tran KL, Piestrzeniewicz-Ulanska D \& Osteen KG. Developmental exposure of mice to TCDD elicits a similar uterine phenotype in adult animals as observed in women with endometriosis. Reproductive Toxicology 200723 326-336. (https://doi. org/10.1016/j.reprotox.2006.09.007)

42 Foster WG. Endocrine toxicants including 2,3,7,8-terachlorodibenzo-pdioxin (TCDD) and dioxin-like chemicals and endometriosis: is there a link? Journal of Toxicology and Environmental Health 200811 177-187.

43 Jirsova S, Masata JV, Drbohlava P, Pavelkova J, Jech L, Omelka M \& Zvárová J. Differences in the polychlorinated biphenyl levels in follicular fluid in individual types of sterility. Ceska Gynekologie 2005 70 262-268.

44 Noori E, Nasri S, Janan A, Mohebbi A, Moini A, Ramazanali F \& Aflatoonian R. Expression of vascular endothelial growth factor receptors in endometriosis. International Journal of Fertility and Sterility 20137114

45 Al-Hamdani NMH \& Yajurvedi HN. Effect of cypermethrin on the ovarian activity and its impact on fertility and pubertal onset of offspring. Beni-Suef University Journal of Basic and Applied Sciences 20176 374-382. (https://doi.org/10.1016/j.bjbas.2017.07.003)

46 Al Hussaini TK, Addelaleem AA, Elnashar I, Shabaan OM, Mostafa R, El-Baz MAH, El-Deek SEM \& Farghaly TA. The effect of follicular fluid pesticides and polychlorinated biphenyls concentrations on intracytoplasmic sperm injection (ICSI) embryological and https://ec.bioscientifica.com https://doi.org/10.1530/EC-20-0135 (c) 2020 The authors Published by Bioscientifica Ltd

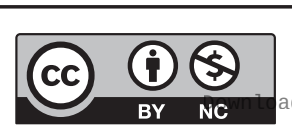

This work is licensed under a Creative Commons Attribution-NonCommercial 4.0 International License. ded from Bioscientifica.com at 04/26/2023 10:54:52AM 
clinical outcome. European Journal of Obstetrics, Gynecology, and Reproductive Biology 2018220 39-43. (https://doi.org/10.1016/j. ejogrb.2017.11.003)

47 Petro EM, Leroy JL, Covaci A, Fransen E, De Neubourg D, Dirtu AC, De Pauw I \& Bols PE. Endocrine-disrupting chemicals in human follicular fluid impair in vitro oocyte developmental competence. Human Reproduction 201227 1025-1033. (https://doi.org/10.1093/ humrep/der448)

48 Campagna C, Sirad MA, Ayotte P \& Bailey JL. Impaired maturation, fertilization and embryonic development of porcine oocytes following exposure to an environmentally relevant organochlorine mixture. Biology of Reproduction 200165 554-560. (https://doi. org/10.1095/biolreprod65.2.554)

49 Liu Y, Wang YL, Chen MH, Zhang Z, Xu BH, Liu R, Xu L, He SW, Li FP, Qi ZQ, et al. Methoxychlor exposure induces oxidative stress and affects mouse oocyte meiotic maturation. Molecular Reproduction and Development 201683 768-779. (https://doi.org/10.1002/ mrd.22683)

50 Merviel P, Cabry R, Chardon K, Haraux E, Scheffler F, Mansouri NB, Devaux A, Chahine H, Bach V, Copin H, et al. Impact of oocytes with CLCG on ICSI outcomes and their potential relation to pesticide exposure. Journal of Ovarian Research 201710 42. (https://doi. org/10.1186/s13048-017-0335-2)

51 Marques-Pinto A \& Carvalho D. Human infertility: are endocrine disruptors to blame? Endocrine Connections 20132 R15-R29. (https:// doi.org/10.1530/EC-13-0036)

52 Yuan B, Liang S, Jin Y-X, Zhang M-J, Zhang JB \& Kim N-H. Toxic effects of atrazine on porcine oocytes and possible mechanisms of action. PLoS ONE 201722 e0179861. (https://doi.org/10.1371/ journal.pone.0179861)

53 Zhou YJ, Huang HR, Zhou J \& Wang LQ. beta-Cypermethrin exposure affects female reproduction by enhancing oxidative stress in mice uterine tissue. Regulatory Toxicology and Pharmacology 2018 98 284-290. (https://doi.org/10.1016/j.yrtph.2018.08.011)

54 Aziz F, Mehboob Z, Jalali S, Shami SA \& Qureshi IZ. Effect of organophosphate pesticide Malathion on in-vitro oocyte maturation, fertilization and embryo development of nili ravi buffalo (Bubalus bubalis). In Proceedings of 6th Asian Buffalo Congress (Vol. 27, p. 30), 2009.

55 Armenti AE, Zama AM, Passantino L \& Uzumcu M. Developmental methoxychlor exposure affects multiple reproductive parameters and ovarian folliculogenesis and gene expression in adult rats. Toxicology and Applied Pharmacology 2008233 286-296. (https://doi. org/10.1016/j.taap.2008.09.010)

56 Jirsová S, Mašata J, Jech L \& Zvárová J. Effect of polychlorinated biphenyls (PCBs) and 1,1,1-trichloro-2,2,-bis (4-chlorophenyl)ethane (DDT) in follicular fluid on the results of in vitro fertilizationembryo transfer (IVF-ET) programs. Fertility and Sterility 201093 1831-1836. (https://doi.org/10.1016/j.fertnstert.2008.12.063)

57 Mahalingaiah S, Missmer SA, Maity A, Williams PL, Meeker JD, Berry K, Ehrlich S, Perry MJ, Cramer DW \& Hauser R. Association of hexachlorobenzene (HCB), dichlorodiphenyltrichloroethane (DDT), and dichlorodiphenyldichloroethylene (DDE) with in vitro fertilization (IVF) outcomes. Environmental Health Perspectives 2012 120 316-320. (https://doi.org/10.1289/ehp.1103696)

58 Bastos AMX, Souza Mdo C, Almeida Filho GLD, Krauss TM, Pavesi T \& Silva LED. Organochlorine compound levels in fertile and infertile women from Rio de Janeiro, Brazil. Arquivos Brasileiros de Endocrinologia e Metabologia 201357 346-353. (https://doi. org/10.1590/s0004-27302013000500003)

59 Palmerini MG, Zhurabekova G, Balmagambetova A, Nottola SA, Miglietta S, Belli M, Bianchi S, Cecconi S, Di Nisio V, Familiari G, et al. The pesticide lindane induces dose-dependent damage to granulosa cells in an in vitro culture. Reproductive Biology 201717 349 356. (https://doi.org/10.1016/j.repbio.2017.09.008)
60 Morinaga H, Yanase T, Nomura M, Okabe T, Goto K, Harada N \& Nawata $\mathrm{H}$. A benzimidazole fungicide, benomyl, and its metabolite, carbendazim, induce aromatase activity in a human ovarian granulose-like tumor cell line (KGN). Endocrinology 2004145 1860-1869. (https://doi.org/10.1210/en.2003-1182)

61 Rossi G, Palmerini MG, Macchiarelli G, Buccione R \& Cecconi S. Mancozeb adversely affects meiotic spindle organization and fertilization in mouse oocytes. Reproductive Toxicology 200622 51-55. (https://doi.org/10.1016/j.reprotox.2005.11.005)

62 Liu Y, Wang YL, He SW, Chen MH, Zhang Z, Fu XP, Fu BB, Liao BQ, Lin YH, Qi ZQ, et al. Protective effects of resveratrol against mancozeb induced apoptosis damage in mouse oocytes. Oncotarget 20178 6233-6245. (https://doi.org/10.18632/oncotarget.14056)

63 Hia ZZ, Zhang JW, Zhou D, Xu DQ \& Feng XZ. Deltamethrin exposure induces oxidative stress and affects meiotic maturation in mouse oocyte. Chemosphere 2019223 704-713. (https://doi. org/10.1016/j.chemosphere.2019.02.092)

64 Houghton FD, Thompson JG, Kennedy CJ \& Leese HJ. Oxygen consumption and energy metabolism of the early mouse embryo. Molecular Reproduction and Development 199644 476-485. (https:// doi.org/10.1002/(SICI)1098-2795(199608)44:4<476::AIDMRD7>3.0.CO;2-I)

65 Trimarchi JR, Liu L, Porterfield DM, Smith PJ \& Keefe DL. Oxidative phosphorylation-dependent and independent oxygen consumption by individual preimplantation mouse embryos. Biology of Reproduction 200062 1866-1874. (https://doi.org/10.1095/ biolreprod62.6.1866)

66 Thompson JG, Partridge RJ, Houghton FD, Cox CI \& Leese HJ. Oxygen uptake and carbohydrate metabolism by in vitro derived bovine embryos. Journal of Reproduction and Fertility 1996106 299-306. (https://doi.org/10.1530/jrf.0.1060299)

67 Donnay I \& Leese HJ. Embryo metabolism during the expansion of the bovine blastocyst. Molecular Reproduction and Development 199953 171-178. (https://doi.org/10.1002/(SICI)10982795(199906)53:2<171::AID-MRD6>3.0.CO;2-F)

68 Leese HJ. Metabolism of the preimplantation embryo: 40 years on. Reproduction 2012143 417-427. (https://doi.org/10.1530/REP-11-0484)

69 Guerin P, El Mouatassim S \& Menezo Y. Oxidative stress and protection against reactive oxygen species in the pre-implantation embryo and its surroundings. Human Reproduction Update 20017 175-189. (https://doi.org/10.1093/humupd/7.2.175)

70 Nasr-Esfahani MH, Aitken JR \& Johnson MH. Hydrogen peroxide levels in mouse oocytes and early cleavage stage embryos developed in vitro or in vivo. Development 1990109 501-507.

71 Nandi S, Gupta PSP, Roy SC, Selvaraju S \& Ravindra JP. Chlorpyrifos and endosulfan affect buffalo oocyte maturation, fertilization, and embryo development in vitro directly and through cumulus cells. Environmental Toxicology 201126 57-67. (https://doi.org/10.1002/ tox.20529)

72 Berger T \& Horner CM. In vivo exposure of female rats to toxicants may affect oocyte quality. Reproductive Toxicology 200317 273-281. (https://doi.org/10.1016/s0890-6238(03)00009-1)

73 Cecconi S, Paro R, Rossi G \& Macchiarelli G. The effects of the endocrine disruptors dithiocarbamates on the mammalian ovary with particular regard to mancozeb. Current Pharmaceutical Design 200713 2989-3004. (https://doi.org/10.2174/138161207782110516)

74 Chiu YH, Williams PL, Gillman MW, Gaskins AJ, Mingez-Alarcon L, Souter I, Toth TL, Ford JB, Hauser R, Chavarro JE, et al. Association between pesticide residue intake from consumption of fruits and vegetables and pregnancy outcomes among women undergoing infertility treatment with assisted reproductive technology. JAMA Internal Medicine 2018178 17-26. (https://doi.org/10.1001/ jamainternmed.2017.5038)

75 Arbuckle TE, Lin Z \& Mery LS. An exploratory analysis of the effect of pesticide exposure on the risk of spontaneous abortion in an https://ec.bioscientifica.com https://doi.org/10.1530/EC-20-0135 (c) 2020 The authors Published by Bioscientifica Ltd

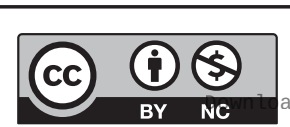

This work is licensed under a Creative Commons Attribution-NonCommercial 4.0 International License. ded from Bioscientifica.com at 04/26/2023 10:54:52AM 
Ontario farm population. Environmental Health Perspectives 2001109 851-857. (https://doi.org/10.1289/ehp.01109851)

76 Willis WO, de Peyster A, Molgaard CA, Walker C \& MacKendrick T. Pregnancy outcome among women exposed to pesticides through work or residence in an agricultural area. Journal of Occupational Medicine 199335 943-949. (https://doi.org/10.1097/00043764199309000-00019)

77 Younglai EV, Foster WG, Hughes EG, Trim K \& Jarrell JF. Levels of environmental contaminants in human follicular fluid, serum, and seminal plasma of couples undergoing in vitro fertilization. Archives of Environmental Contamination and Toxicology 200243 121-126. (https://doi.org/10.1007/s00244-001-0048-8)

78 Meeker JD, Maity A, Missmer SA, Williams PL, Mahalingaiah S, Ehrlich S, Berry KF, Altshul L, Perry MJ, Cramer DW, et al. Serum concentrations of polychlorinated biphenyls in relation to in vitro fertilization outcomes. Environmental Health Perspectives 2011119 1010-1016. (https://doi.org/10.1289/ehp.1002922)

79 Milesi MM, Alarcón R, Ramos JG, Muñoz-de-Toro M, Luque EH \& Varayoud J. Neonatal exposure to low doses of endosulfan induces implantation failure and disrupts uterine functional differentiation at the pre-implantation period in rats. Molecular and Cellular Endocrinology 2015401 248-259. (https://doi.org/10.1016/j. mce.2014.11.028)

80 Guney M, Oral B, Demirin H, Take G, Giray SG, Altuntas I \& Mungan T. Fallopian damage induced by organophosphate insecticide methyl parathion, and protective effect of vitamins $\mathrm{E}$ and $\mathrm{C}$ on ultrastructural changes in rats. Toxicology and Industrial Health 200723 429-438. (https://doi. org/10.1177/0748233707076773)

81 Paoloni-Giacobino A. Epigenetic effects of methoxychlor and vinclozolin on male gametes. In Vitamins and Hormones, Vol. 94, pp. 211-227. Cambridge, MA, USA: Academic Press, 2014. (https://doi. org/10.1016/B978-0-12-800095-3.00008-0)

82 Baligar PN \& Kaliwal BB. Carbofuran induced block of compensatory ovarian growth in hemicastrated albino mice. Toxicology 2004204 87-95. (https://doi.org/10.1016/j.tox.2004.06.027)

83 Guerrero-Bosagna C \& Skinner MK. Environmentally induced epigenetic transgenerational inheritance of male infertility. Current Opinion in Genetics and Development 201426 79-88. (https://doi. org/10.1016/j.gde.2014.06.005)

Received in final form 8 April 2020

Accepted 7 May 2020

Accepted Manuscript published online 7 May 2020
This work is licensed under a Creative Commons Attribution-NonCommercial 4.0 International License. ded from Bioscientifica.com at 04/26/2023 10:54:52AM 